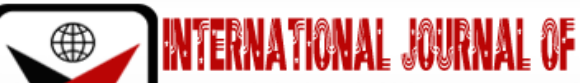

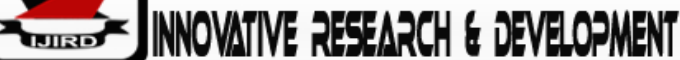

ISSN 2278-0211 (Online)

\section{Assessing the Socio-Economic Impact of the Damba Festival on the Lives of the People of Yendi in Ghana}

\author{
Abukari Majeed \\ Lecturer, Department of Hospitality and Tourism Management, \\ Tamale Technical University, Ghana
}

\begin{abstract}
:
This study focused mainly on the socio-economic impact of the Damba festival on the people of Yendi, in Ghana. It also looked at how the festival is celebrated among the people of Yendi and finally, examined the extent of its contribution to national development. Damba, as a festival by Dagomba, means 'Big Dance' in Mandingo word and in Dagbani, it is 'Danbahi' meaning 'shake yourself free'. At first, the festival was not celebrated by Dagomba until during the reign of Naa Zanjina in the sixteenth century when it was decided that it should be used to replace their old harvest festival with the aim of linking it up to the birth and naming of Prophet Mohammed (SAW) for its commemoration. The methods used in the study were interview and focus group discussion with the help of instruments like questionnaire and interview guide. From the study, it was found out that the elders dominated the various activities carried out in the course of the celebration. This practice does not make the youth to learn the cultural heritage of the traditional area. Therefore, I recommend that the people particularly the youth should be well integrated in all the activities of the celebration to be more conversant with its celebration. Secondly, it was realized that the celebration occurred through the main streets of the area and finally staged at the king's palace which is not extensive enough to accommodate everybody and, this poses security threat to the feeble ones especially children since stampede could be caused. Therefore, it is recommended that a wide area, if even it is outside the king's palace, could be secured for the celebration of the festival since that can help provide enough security. Also, the study showed that the celebration sometimes results in misunderstanding between couples which can bring about divorce since the couples accused each other of being morally weak and using the festival to satisfy their selfish desires. As a result, it is recommended that law should be passed banning married women from attending the festival since this can minimize the accusations. Finally, it was observed that the festival can play a major role in the cities and local communities; it develops local pride and identity for the local people. It could also play an important role in the national and host community in destination planning which could enhance and link tourism and commerce in the area.
\end{abstract}

Keywords: Damba, tourism, belkulsi, festival, destination

\section{Introduction}

Festivals are celebrated by almost every society in Ghana, and Yendi as a society is no exception. Each of the festivals is celebrated with an aim or objective. For instance, the people of Elimina, on the first Thursday of New Year, celebrate Edina Buronya festival to welcome the year, purify and offer sacrifice to the gods. Rice festival is also celebrated by the people of Akpafu in the Volta Region; Lulu Kpledo festival by the people of Prampram in the Greater Accra Region, Aboakyir (Deer hunting) festival by the people of Winneba among others.

Other festivals we can think about are National Festival of Arts and Culture (NAFAC) which is a biennial cultural show planned and executed by the National Commission on Culture since 1992 in order to inculcate in the youth through dance, drama and the traditional music which are positive cultural values that our forefathers have bequeathed to us. It is an attempt to preserve and pass on these values to the future generations. Also, we have Pan-Africa Historical, Theatre festival (PANAFEST). This is also a major biennial event mooted and designed by Efua Sutherland in the mid-1980s as a cultural forum of African and the people of African descent as well as friends of the Africa continent committed to the noble cause and development of Pan-Africanism (Ministry of Tourism, Arts and Culture 2018).

Damba as a festival is originally linked to Islam meant to mark the birth and naming of Prophet Mohammed (SAW). The festival, in terms of culture, length of the period of celebration and the number of people involved in the celebration may be regarded as the most important festival of the Dagomba (Mahama, 2004). It has gradually taken on a traditional rather than Islamic tone. Damba which means 'Big dance', in Mandingo word, is not celebrated by Dagomba 
alone but also other tribes such as Gonjas, Mamprusis and Nanumbas, all in Northern Ghana. Wala people in Upper West Region also celebrate it. But each of the celebrants has the way they celebrate the festival. Nevertheless, the celebration of the festival is geared towards one goal-the naming of the Prophet Mohammed (SAW).

However, the word Damba is strongly believed to be a Dagomba word 'Dambahi' meaning 'shake yourself free'.

Yendi, which is the traditional seat of Dagbon, is geographically located in the North-Eastern part of Ghana. It is the Municipal Head Quarters of Eastern Dagbon Municipal Assembly and it is next to Tamale, the Regional Capital of Northern Region with a population of about fifty-two thousand inhabitants (GSS, 2010).

Damba festival, at first, was not being celebrated by Dagomba and for that matter the people of Yendi. They had their own festival (the yam festival) which was celebrated every year purposely to give thanks to their ancestral gods for the blessings offered them during the farming season and to ask for more of such blessings during the years to come. It was during Na Zanjina's rein that they started celebrating it. This great King of Dagbon reined from 1648-1677.

The festival is celebrated usually in the dry season. It was during this period that Prophet Mohammed (SAW) was born. Therefore, it is celebrated around this period in order to commemorate his birth and naming (Mahama 2004). During this period, peace is restored among the people. The customs, culture and traditions of the people are also inculcated into the people. Arrangements and prayers are normally offered to God for long lives and prosperity.

The celebration of festivals contributes to the development of the communities concerned in one way or another. However, as far as the Damba festival is concerned, it is always during such periods that the people of Yendi normally waste their resources. The people normally sell their cattle and food stuffs in order to celebrate the festival in a grand style. As Mahama (2004) postulated that before the appearance of the moon for Damba, young boys and girls pressurize their parents and guardians to buy for them in advance clothes they wish to wear during this important festival. Therefore, at the end of the festivities the people are normally left with little or nothing at all to live on and to even take proper care of their children. This thus makes it impossible for the two issues to be easily reconciled. The extent to which the celebration of the Damba festival leads to the development of Yendi area and for that matter the people of Yendi has never been determined. It is on the basis of the above that the study seeks to examine the socio-economic impact of the festival on the lives of the people of Yendi and the extent to which the festival contributes to national development.

\section{Literature Review}

Festival is an event usually staged by a local community which centers on some unique aspect of that community. Among many religions, festival is a set of celebration in honour of God or gods. Festivals of many types, serve to meet specific social needs and duties, as well as to provide entertainment. These times of celebration offer a sense of belonging to religious, social, or geographical groups. Modern festivals that focus on cultural or ethnic topics seek to inform members of their traditions. In times past, festivals were times when the elderly shared certain knowledge with the next generation. Historic festivals often provide a means for unity among families and for people to find mates.

In Africa, the festival is of a religious nature and involves a lot of dancing and music. Dancers wear masks and each dance tells a story. The stories range from a good ghost who look after their crops and scares away the bad ghosts who try to spoil the food. Chantler (1973) postulated that traditional Ghanaian festivals, updated and modernized, continue to have the same significance of former times where the world of religious, social, moral, political, cultural and historical events often emerged. According to Wyllie (1994) Ghanaians are socialized to value shared experiences. For the average Ghanaian, the sharp increase in the number of annual local and national festivals represents their rich cultural heritage and the uniqueness of ethnic and regional differences. In times past as espoused by Sheilah and Ekong (1997), annual events lessened rural isolation and contributed to a sense of extended community with migrants to urban centers. This urban-rural connection continues to represent significant financial inputs into the rural economy and a constant labour resource for the urban area. Ethnic and lineage affiliation as important markers of self- identity, are also exemplified today by community members who return for communal celebrations thereby validating the legitimacy of 'traditional beliefs and practices' in the midst of modernity (Sheilah and Ekong (1997). Festival is a regular public celebration that is organized by members of the community and has clear and strong community support. Smith (2003), on his part, considers festivals to be described as an entrée for the tourist seeking to engage with the destination and to penetrate the quotidian. He continued that festivals often would serve as a means of reviving a local tradition, and would offer communities the chance to celebrate their cultural identity, Smith (2003). The concept of identity, he however contended, sometimes poses serious problem for younger community members who often have a sense of dual identity, especially those of either first- or second-generation immigrants, Smith (2003). Thus, festivals can assist to increase racial tolerance through cross-cultural exchange and education. The implication here is that the involvement of children through local schools in various workshops, events and processions assists in establishing an understanding of cultural diversity.

In the 'Profile of Damba Festival of Northern Ghana', Tuya-Naa Abubakakr Von-Salifu laid bare that the Damba festival began to be celebrated in Dagbon during the reign of Ya-Na Zanjina who ruled from 1648 - 1677, Von-Salifu (1997). He continued that Na Zanjina during his reign sent an emissary to his traditional father, the MogNaba of presentday Burkina Faso for a spiritual leader (Imam). When this request was met and the spiritualist arrived, he was task to reorganize the Ya Na's court which subsequently enjoined him to convert the subjects to the Islamic religion; a novelty to the Dagomba. YidanMoli as the spiritual leader was called, advised that the birth and naming ceremony of Prophet of Islam, Mohammed (SAW) should be observed as an integral part of Islam, Von-Salifu (1997). Na Zanjina heard drumming during one rehearsal and summoned YidanMoli who explained that this was only a rehearsal and the beginning of the bigger festival. He was only hosting the rehearsal to shape it for a climax which will take place at the palace. The eleventh day of the third Luna month of Dagbon calendar signified the birth of Prophet Mohammed, Mahama (2004). The seventeenth day, postulated Von-Salifu (1997), was to be the naming ceremony of Prophet Mohammed (SAW). Kojo 
(1989) also claimed that the Damba festival which was originally a traditional festival is now a traditional and religious festival because it is combined with the birth and naming of Prophet Mohammed. It is therefore celebrated by both Moslems and non-Moslems in the Northern and Upper Regions of Ghana, especially, among the Dagomba, the Wala, the Mamprusi, the Gonja and the Nanumba. He continued that the main aim of celebrating this festival is to remember the birth and naming of Prophet Mohammed (SAW), Kojo (1989). That it is an annual affair which falls on the Twelve of RabirAli-Awwal, which is the month in which Prophet was born, Kojo (1989). The celebration starts with the appearance of the new moon of Rabir-Ali-Awwal which is the third month on the Islamic calendar. When the moon appears, it is called the Damba moon. Its appearance is welcomed with traditional drumming and dancing throughout the town or village. Damba festival is put into four parts - The Rehearsal, Somo and NaaDamba, Mahama (2004). The Rehearsal starts with the appearance of the Damba Moon to the tenth day of it. The second part comes off on the eleventh of the month. The third part comes off on the seventeenth day of the month and the fourth part comes off on the eighteenth of the month, Mahama (2004). Nukunya (2003), stated that the Dagomba traditional political system is clearly centralized since they have Kings or Chiefs who exercise jurisdiction over the wide areas. He continues that the descent practice by most of the centralized states in the North resemble bilateral or cognatic descent rather than patrilineal that the cross-cousin marriage occurs among such societies as Dagomba, Gonja and Mamprusi, Nukunya (2003). Mahama (2004) stipulated that the Ya-Na is the Head of the State Council of Dagbon. He presides over and directs the affairs of the Council. The executive powers of Dagbon resides in the Ya-Na. He is assisted in the exercise of these powers by an Advisory Council of Elders, Mahama (2004).

Before the start of the morning session of the NaaDamba, Ya Na sits in state to receive homage from his sub-chiefs, village headmen, elders, senior princes and other customary dignitaries. The village headmen are enjoined by custom to bring to the King fowls or guinea fowls, foodstuffs and sometimes cash. These gifts are of great assistance to the King in the celebration of the festival, Mahama (2004). The State Council of Dagbon, espoused by Mahama (2004), composed of the Ya-Na and the divisional heads such as Karaga, Mion, Yelzoli, Gulkpiegu, Kunbungu, Demong, Savelugu, Gushegu, Nanton, Tolon, Kworli and Chereponi. The Dagbon Council of State met only in emergency situations, and the 'day-to-day' administration of the state was done by the Ya-Na and his elders (Nayili-kpamba) in the judicial council, Arhin (1996).

\section{Research Approach}

Basically, two approaches were used including Focus Group Discussion and Interview, particularly SemiStructured interview Methods. The researcher also made use of the questionnaire to supplement the two major approaches.

The focus group technique, according to Bryman (2004), is a method of interviewing that involves more than one, usually at least four, interviewees. Essentially, it is a group interview which typically emphasizes a specific theme that is explored in depth. The study applied this technique because it allowed the researcher to get an understanding about why people feel the way they do. It also made it possible for the participants to bring to the fore, issues in relation to a topic that they deemed important and significant. Finally, it offered the researcher the opportunity to study the ways in which individuals collectively make sense of a phenomenon and construct meanings around it.

Kvale defines interview as 'a specific form of human interaction in which knowledge evolves through dialogue' Kvale (1996: 125). There are many ways of conducting interviews among which are face-to-face, conversation, telephone interview, internet interview and so on. However, narrowing it down to semi-structured interview, Kvale defines semistructured interview as an 'interview whose purpose is to obtain descriptions of the life world of the interviewees with respect to interpreting the meaning of the described phenomenon' (Kvale, 1996: 6). In this form of interview, it is flexible in its methods of data collection such that the interviewer has several questions in general forms organised in an interview guide. In the course of the interview, the interview guide serves as a guide to cover the list of the themes itemised in it such that several wide ranges of sub-questions are covered in the interview. In this way, some questions can be ignored to avoid repetition while some additional follow up questions can be asked during the interview process. Talking about group interview, Bryman looks at it as a 'situation in which members of a group discuss a variety of matters that may be only partially related' (Bryman 2004:113). This type of interview has the tendency of so many respondents having the opportunity to take part in the interview process.

For the interview method, some opinion leaders of the area were interviewed including Dugu Wulana, Bolin Lung $\mathrm{Na}$, MmaGbanzaling, Mmakazia, among others including the Municipal Chief Executive of Yendi.

Finally, some questionnaires, numbering up to 100, were distributed to the people of Yendi for them to provide their responses.

\subsection{Background of the Study Area}

Yendi is the traditional seat of Dagbon with population of about fifty-four thousand four hundred and eleven $(54,411)$ inhabitants. It is to the North - Eastern part of Tamale, the regional capital of Northern Region and it is about 96km drive from Tamale. Yendi, to the North, is sharing boundary with a village called Gbambaya, to the south with Zugu, to the East with Zang and to the West with Kulikpeni Duli (a Konkomba village). This traditional seat is occupied by a great personality, the Ya-Na, the Overlord of Dagbon.

The fifty-four thousand four hundred and eleven $(54,411)$ inhabitants of the area have their political, social, economic, religious and cultural life they lead. 


\subsection{The Political Life of the People}

Politically, Yendi is the traditional seat of Dagbon and the traditional Political system of Dagomba is that of the centralized type occupied by Ya Na who is the Overlord of Dagbon exercising jurisdiction over the entire Dagbon state. He is assisted in the exercise of this jurisdiction by an Advisory Council of Elders, Mahama (2004).

Outside Yendi, his powers cover places such as Mion, Karaga and Savelegu. The occupants of any of these three (3) keys areas as chiefs of his jurisdiction stand the chance of succeeding the king after his death. Therefore, they are by tradition, occupied by the sons of the past Kings or a king who is yet ruling Mahama (2004). However, for about three decades now there has been a problem with the kingdom regarding the succession between Abudu and Andani gates where each of them accusing the other of not properly following the succession line before becoming Ya Na. These accusations eventually led to a conflict in Yendi which brought about the death of the late king, Ya-Na Yakubu Andani II. The effects of this war, which occurred in March 2002, on the social and economic life of the people of Yendi cannot be overemphasized. This is because the war led to breakage of some marriages, and even some investors were scared to the extent that those already in Yendi were running away from Yendi and those intending to go into did not longer wanted to do so. Even medical doctors did not want to go to Yendi. Other areas the king controls over aside the main three (3) areas include Nanton, Tolon, Diary, Zabzugu, Gushegu, Sang, Salinkpang, Tugu, Gulkpegu, Ngani, Dalon, Gbullung, Kumbungu, Vogu, Sagnarigu to mention but a few. Ya-Na sub-enskins them (the chiefs of the above-mentioned areas) who will celebrate Damba festival at their various places on his behalf just as done by the various Districts Chief Executives and the Regional Ministers during the Independence Day celebration on behalf of the President of the Republic of Ghana.

However, in Yendiitself,Ya-Na, the Overlord, has subjects such as MbaDugu, Kuga Na, Kpatu Na, Gundo Na Balo Na, Zohi Na YidanaMoli, YidanaKambala, Yidana Baba, YeniLimam, Namo Na, Yemba Na, Gagbon Dana to mention but few who, in one way or another assist him domestically in the day - to - day running of his administration and each one of them has a specific role he or she plays in the skin ship of the kingdom. Also, the area has some lineages and clans each having its head that pays respect to the king from time to time. In addition to the above, the modern political system also plays a significant role in the political life of the area. For instance, the area is the Capital of Eastern Dagbon accommodating the Municipal Chief Executive, the Municipal Co-ordinating Director, Presiding Member and various Assembly men of the Local Assemblies of the Municipality. These people see to the day - to - day running of the Assembly, and in times of festivities, they assist so much in providing aids including security since the Municipal Chief Executive presides over the Municipal Security Council, which includes the police, the military, the BNI among others.

\subsection{The Social Life of the People}

Socially, the people of Yendi interrelate very well unlike in the immediate past where there were instances when some misunderstandings arise regarding the issue of Abudu and Andani. The area is not only occupied by the Dagomba but also other tribes such as Konkombas, Ewes, Ashantes, Chakosis, Gonjas among others. There is also smooth relationship between Dagomba and each of these tribes. Even, there has been some cross marriages between Dagomba and the other tribes.

The people of the area and for that matter Dagomba are polygynous because about $52 \%$ of those married have more than one wife. And those who have one wife, about $80 \%$ of them are still considering the option of raising up the tally. Aside this polygynous system, the people also practice systems of marriages such as Infant Betrothal where a baby girl aged form birth to ten years or yet to be born girl is promised in marriage to a male much older. Arranged marriages where there is an agreement between two families to surrender their son or daughter into a marital union. Often times, the bride or the groom may be known or not known to each other and finally, there is preferential marriages which are perhaps the most common in every part of the country. Under this type, an adult male has the option to choose his bride by himself, but only from families favoured by his parents. Cross cousin marriages are also common with the people. However, they forbid parallel cousin marriages.

Finally, the people's life is basically the extended family system since every family house is a composition of the family head and his children or biological children, his brothers and their biological children even to the extent of catering for the nephews and nieces among others.

\subsection{The Economic Life of the People}

Economically, the people are predominately farmers with majority being peasant and subsistent farmers. It is only few who farm on commercial basis with some modern farm implements such as tractors, combine harvesters among others.

They cultivate crops such as maize, millet, rice, sorghum, groundnuts, cowpea, pigeon pea, yams, cassava, and sweet potato (as root crops). Their farming activities depend solely on natural rainfall without irrigation schemes.

Livestock and poultry rearing are also practiced by the people though on a limited scale. The livestock and the poultry reared include; cattle, sheep, goats and fowls such as guinea fowl, turkey, duck, fowl and dove among others. With the exception of the cattle which are normally kept in Kraal and only sent out to search for pasture, the rest of the animals are kept on free range basis to be catered for by nature.

The system of farming employed by these people is basically mixed cropping; where on a piece of land more than one crop is grown, mono culture; where on a particular piece of land one crop is grown over and over every year and mixed farming; where those who rear animals especially cattle normally will move the cattle to a new land as a source of fertilizer for his crops. Land fallowing is also being practiced by the people. Here, a particular piece of land which has been cultivated for long is left to fallow for four to five years before getting back onto it for farming. 
The area also has some traders who basically do middlemen or women activity. These people buy and sell surpluses of the farmers and the livestock and poultry reared by these farmers. Normally, they sell this out to the outsiders who come looking for them to be sent to their places. But what is of good note is the fact that many of these traders are also farmers in some sense.

There are other people who are engaged in other economic activities such as public service, civil service, all earning salaries or wages/commission, butchers, blacksmiths, goldsmiths to mention but a few. However, there are yet others who virtually do nothing. These people are unemployed and depend on family and friends for their livelihood. The economists refer to such people as the autonomous consumers since their life is on their relations or relatives who are working Koutsoyiannis (1979).

\subsection{The Religious Life of the People}

Predominately, the people of Yendi are Moslems. The area also has Christians, who are in the minority category. Almost all the Christian religious denominations are found in this area including Presbyterians, Aposthelics, Catholics, Baptists and Assemblies of God among others. The traditionalists also live in Yendi. These people worship their lord through the intermediary gods. The gods could be an individual property or a family property. But the individual gods eventually become the family god after his death since it will be taken over by his children and grand-children, Mahama (2004). They believe so much in the worship of their ancestral gods usually pouring libations and offering sacrifices to the gods for the good things done to them and to ask for more blessings from them. The traditionalists 'mode of worship is mostly in the form of libation pouring which could be water or alcohol and this is relevant in times of festivities.

However, there are those who belong to both Christianity and Traditional religion. Also, some belong to both Islamic religion and Traditional religion. Such people claim that they are either Moslems or Christian but where necessary they still consult the ancestral gods for assistance. They usually do that secretly.

\subsection{The Cultural Life of the People}

Culturally, the people of Yendi predominately speak Dagbani, the language of Dagomba. Even the minority tribes living there also speak Dagbani since the major transactions carried out in the area are conducted in Dagbani. The houses in which the people live have their rooms built mostly in round forms with some thatches on top of them as their roofs, especially in the traditional area called Nayili Fong (the area of the chief's house). Gbewa Palace is located in this area in Yendi. This palace is also designed similarly, but this one, as the Overlord's house, has a lion drawn on the wall of a big hall (Zong) to the house at the fore-court of the palace as an emblem of the skin.

The staple food of the people is Tuo-Zaafi (TZ) which is usually provided in the afternoon during lunch and in the night during dinner (supper) but in the mornings some porridge is supplied sometimes with groundnuts cake as breakfast. Therefore, maize, millet and sorghum are culturally farmed and patronized by the people of Yendi since their diets are obtained from these grains.

In terms of their dress code, the people are identified with smock which is principally worn in times of festivities, however, some majority of them are Moslems, the Islam way of dressing is also identified with them. The men wear long gown while the women especially the married ones are dressed up with veil covering their head and neck. During festive occasions some of the women wear traditionally woven clothes around their chests when they are not wearing blouses and around their waists when a blouse is worn Mahama (2004).

Regarding their value system, they cherish so much respect for elderly. It is even recommended that the young ones should always greet an elderly while squatting. Greetings are also valued by them and if one does not take it a habit of greeting others, such a person is usually considered as a bad person and attracts public gossip and comments.

The people are also hospitable especially to their guests to the extent of providing them with the best entertainment they could offer them should they have one. Usually, they will kill for them the oldest cock or guinea fowl they have in their pen and select, for their food to be prepared, the best or biggest tubers of yams they have from their farms. Also, as peasant and subsistent farmers, the people use simple farming tools as cutlasses, hoes, mattocks, sickles, pick axes, watering cans, cattle dung as fertilizers among others. Only few modern farms implement such as tractors, combine harvesters, chemical fertilizers, weedicides, and pesticides among others are used. Those implements are used by the few farmers who farm on commercial basis solely for commercial purpose.

Finally, their festive occasions like Bugum festival, Damba festival, Kpini festival to mention just a few are found being celebrated in the full glare of the chiefs or the King on horseback. This horse is dressed up in the full regalia of the traditional area. About music, the place has violinists (Gonje), Tomtom beaters (Lunsi), Drum beaters (Akarima) and several others. With the exception of market days, naming ceremonies and wedding ceremonies where only the violinists and the Tomtom beaters provide music, the rest together with the violinists and the Tomtom beaters are found providing music during festive occasions and on funeral grounds of important personalities of Yendi.

\section{Data Analysis and Presentation}

This chapter analyses and presents various responses the respondents made relative to the questionnaire. It also narrates how Damba festival is celebrated among the people of Yendi.

\subsection{Socio-Demographic Characteristics}

\subsubsection{Sex Structure}

The Table below illustrates the sex structure of the respondents approached during the research. 


\begin{tabular}{|c|c|c|}
\hline Sex & Frequency & Percentage \\
\hline Male & 55 & 55.0 \\
\hline Female & 45 & 45.0 \\
\hline Total & 100 & 100.0 \\
\hline
\end{tabular}

Table 1: Sex Distribution

Source: Field Survey 2019

Based on the above Table, it is observed that out of the total number of Respondents targeted, fifty-five (55\%) percent of them represents the male category while forty-five (45\%) percent represents the female category.

4.1.2. Age Structure

The Table below depicts the age structure of the respondents contacted for the study:

\begin{tabular}{|c|c|c|c|c|}
\hline Age Interval & Male & Percentage & Female & Percentage \\
\hline $18-22$ & 11 & 20 & 6 & 13 \\
\hline $23-27$ & 10 & 18 & 7 & 16 \\
\hline $28-32$ & 10 & 18 & 4 & 9 \\
\hline $33-37$ & 10 & 18 & 7 & 16 \\
\hline $38-42$ & 6 & 10 & 5 & 7 \\
\hline $43-47$ & 3 & 6 & 3 & 7 \\
\hline $48-52$ & 2 & 4 & 3 & 9 \\
\hline $53-57$ & 1 & 2 & 4 & 100 \\
\hline $58+$ & 2 & 4 & 45 & 7 \\
\hline Totals & 55 & 100 & & \\
\hline
\end{tabular}

Table 2: Age Distribution

Source: Field Survey 2019

From the above Table, the ages of the respondents were ranged; starting from 18-22, 23-27, etc. up to 58+ and each range had its corresponding percentage for both male and female.

\subsection{The Structure of Marital Status}

The marital status of the respondents has been captured in the Table below;

\begin{tabular}{|c|c|c|c|c|}
\hline Marital Status & Male & Percentage & Female & Percentage \\
\hline Single & 22 & 40 & 16 & 36 \\
\hline Married & 19 & 35 & 22 & 49 \\
\hline Divorced & 9 & 16 & 5 & 11 \\
\hline Widowed & 5 & & 2 & 4 \\
\hline Separated & 55 & 9 & & 100 \\
\hline Total & & 100 & 45 & \\
\hline
\end{tabular}

Table 3: Distribution of Marital Status

Source: Field Survey 2019

From the Table above, it is realized that forty percent of the male respondents were single, thirty-five percent of them were married, sixteen percent of them were divorced and nine percent of them were separated. But, that of the female category, thirty-six percent of them were single, forty-nine percent of them were married, eleven percent of them were divorced and four percent of them were widowed.

\section{The Structure of Occupation}

The occupation of the respondents was identified and captured in the Table below.

\begin{tabular}{|c|c|c|}
\hline Job Type & Frequency & Percentage \\
\hline Teachers & 44 & 44 \\
\hline Public servants & 10 & 10 \\
\hline Civil servants & 16 & 16 \\
\hline Farmers & 17 & 17 \\
\hline Traders & 13 & 13 \\
\hline Total & 100 & 100 \\
\hline
\end{tabular}

Table 4: Occupational Distribution

Source: Field Survey 2019 
The Table above showed that forty-four percent of the respondents were teachers, ten percent of them were public servants, sixteen percent of them were civil servants, seventeen percent of them were farmers and thirteen percent of them were traders.

\subsection{Educational Background}

The table below designs the structure of the educational background of the respondents to my questions.

\begin{tabular}{|c|c|c|}
\hline Level of Education & Frequency & Percentage \\
\hline GCE O' Level & 20 & 20 \\
\hline Senior High School Certificate & 24 & 24 \\
\hline GCE A' Level & 30 & 30 \\
\hline Diploma & 10 & 10 \\
\hline Bachelor degree & 10 & 10 \\
\hline None & 6 & 6 \\
\hline Total & 100 & 100 \\
\hline
\end{tabular}

Table 5: Distribution of Education

Source: Field Survey 2019

From the above Table, it is observed that twenty percent of the respondents were 0' level holders, twenty four percent of them were Senior High School certificate holders, thirty percent of them were A' level holders, ten percent of them were Diploma holders, ten percent of them were Degree holders and six percent of them were not educated.

\subsection{Religious Denomination of Respondents}

The religious denomination of respondents was captured and the results shown in the Table below.

\begin{tabular}{|c|c|c|}
\hline Name of Religion & Frequency & Percentage \\
\hline Islam & 55 & 55 \\
\hline Christianity & 25 & 25 \\
\hline Traditional Religion & 20 & 20 \\
\hline Total & 100 & 100 \\
\hline
\end{tabular}

Table 6: Distribution of Religion

Source: Field Survey 2019

Out of the total number of the respondents, fifty-five percent represents Muslims. Twenty-five percent represents Christians and twenty percent represents Traditionalists.

\subsection{The Damba Celebration Process}

All the respondents, in responding to the question whether they had ever taken part in the celebration of the festival, said that they had ever taken part in the celebration of the festival and as to how the festival was celebrated; seventy-eight percent of them claimed that the appearance of Damba crescent marks the beginning of the celebration amidst drumming and dancing after the King had been informed about the appearance of the moon in the night of the first day of the appearance. The wives sung songs of praises. Then, the second phase of the celebration comes off after the picking of pebbles from spread rice on a mat on the eleventh day of the month, this second phase is called 'Somo Damba' or 'Moli Damba'. They said that the third stage comes off also after picking of pebbles from spread rice on a mat on the seventeenth day which is also known as 'Naa Damba' or 'Big Damba'. Finally, that the 'seeing off' part, (Belkulsi) comes off on the eightieth day of the month in the evening. However, twenty-two percent of the respondents said the festival starts on the tenth day which is the picking of the pebbles from rice spread on a mat followed by 'Somo Damba' and another picking of pebbles from rice spread on a mat on the sixteenth day followed by 'Naa Damba' and finally 'Belkulsi' on the eighteenth day evening. But both groups specified that on both the 'Somo' and 'Naa Damba' days, a cow is slaughtered after the king and Moli together with some subjects make some rounds around the cow on the festive ground. This will be followed by Quranic recitation by Moli, the chief spiritualist.

\subsection{Significance of Damba Festival}

The searcher solicited the views of the respondents on the significance of the damba festival and their responses were captured in the Table below:

\begin{tabular}{|c|c|c|}
\hline Response from Respondents & Frequency & Percentage \\
\hline Religious and cultural significance of it & 97 & 97 \\
\hline No response & 3 & 3 \\
\hline Total & 100 & 100 \\
\hline
\end{tabular}

Table 7: What Damba Signifies in Dagbon

Source: Field Survey 2019 
It is realized from the Table above that ninety-seven percent of the respondents gave both religious and cultural significance to the festival. According to them the festival religiously signifies the commemoration of the birth and naming of the Prophet Mohammed (SAW) and culturally or traditionally, that it signifies the inculcation of the cultural heritage of Dagbon. That it serves as a platform during which the King resolves disputes and unifies his subjects and finally, that it is a time to meet with old friends and to make new friends. However, three percent of the respondents could not respond to the question.

\subsection{Venue for the Celebration of the Festival}

The respondents were also asked to indicate where the damba festival is normally celebrated and their views were taken and recorded in the Table below:

\begin{tabular}{|c|c|c|}
\hline Responses of Respondents & Frequency & Percentage \\
\hline The king's palace & 92 & 92 \\
\hline The principal streets & 8 & 8 \\
\hline Total & 100 & 100 \\
\hline
\end{tabular}

Table 8: The Part in Yendi where the Celebration of the Festival Occurs

Source: Field Survey 2019

Ninety-two percent of the respondents, according to the table 8 above, claimed that it occurred in the king's palace. But eight percent of them claimed rather that the celebration occurs through the principal streets of Yendi before it finally stages at the palace.

\subsection{Period Damba Festival Started in Dagbon}

The researcher wanted to know from the respondents when damba festival started in dagbon and their responses captured in Table 9 below:

\begin{tabular}{|c|c|c|}
\hline Responses from Respondents & Frequency & Percentage \\
\hline In the sixteenth century & 90 & 90 \\
\hline Not known & 10 & 10 \\
\hline Total & 100 & 100 \\
\hline
\end{tabular}

Table 9: The Year the Celebration of the Festival Started Source: Field Survey 2019

From Table 9 above, ninety percent of the respondents claimed that it started in the sixteenth century during which Ya-Na Zanjina reined the Dagbon kingdom. That since it has something to do with Islam and Islam had its way to Dagbon during his reign between (1648 -1677). But ten percent of them said that Damba in Dagbon was born with Dagbon and that Dagbon is older than Islam and for that matter it cannot be related to Islamic calendar. Therefore, the date is not known.

\subsection{Reign in Which Damba Festival Started}

The researcher wanted to know under whose reign damba festival started and their views were gathered and tabled below:

\begin{tabular}{|c|c|c|}
\hline Responses from Respondents & Frequency & Percentage \\
\hline It was started by Na Zanjina & 89 & 89 \\
\hline Not known & 11 & 11 \\
\hline Total & 100 & 100 \\
\hline
\end{tabular}

Table 10: The King Who Started Its Celebration

Source: Field Survey 2019

From the above table, eighty-nine percent of the respondents said it was Na Zanjina who started its celebration. But eleven percent of them said it is not known as to who started its celebration.

\subsection{The Role of the King in Damba Celebration}

The role the King played in the celebration of damba festival was also sought from the respondents and their views tabled as below: 


\begin{tabular}{|c|c|c|}
\hline Responses from Respondents & Frequency & Percentage \\
\hline He ensures smooth celebration of the festival & 40 & 40 \\
\hline He provides materials needed for the festival & 35 & 35 \\
\hline He dances round the Damba cow & 25 & 25 \\
\hline Total & 100 & 100 \\
\hline
\end{tabular}

Table 11: The Role the King Plays in the Celebration

Source: Field Survey 2019

In response to the role the king does play in the celebration of the festival, table 11 above shows that forty percent of the respondents said that the king ensures the smooth celebration of the festival by assembling all the subjects. Thirtyfive percent of them claimed that the materials needed for the festival are provided and Twenty-five percent of them asserted that he performs some cultural rites such as dancing round three times the Damba cow before it is slaughtered to grace the festivity.

\subsection{Role the King's Subjects Play in the Celebration}

In response to the role the subjects play in the celebration of the festival, eight percent of the respondents said a subject like NgubKahi Na prepares the meat of the slaughtered cow, MbaDugu and others see to the Belkulsi, Somo and Moli dance round the cow to be slaughtered on the festive ground. Also,YanLimam prays to God during the celebration, the distribution of the cooked food for the guests is done by War Kpan $\mathrm{Na}$ and the tail of the slaughtered cow is cut by Kumlana for keeps to be counted in order to tell the number of years the king has ruled after his death. Twenty percent of the respondents claimed that some of the subjects help the king by providing him with some materials such as the cow, the rice, and cash among others needed for the celebration.

\subsection{Roles the Wives Play in the Celebration}

All the respondents agreed that the wives of the king do play a role in the celebration of the festival saying that the wives sing songs of praises praising the king and his ancestors. That they are also in charge of cooking in the palace to cater for the guests who come to celebrate the festival. Finally, that they represent the king to see to the 'seeing off' (Belkulsi) part of the festival.

\subsection{Organization of Materials for the Celebration}

The respondents were made to indicate the source(s) of materials for the celebration of the festival and their responses entered in Table below:

\begin{tabular}{|c|c|c|}
\hline Responses from Respondents & Frequency & Percentage \\
\hline From his pocket and donations & 68 & 68 \\
\hline From sales of land & 32 & 32 \\
\hline Total & 100 & 100 \\
\hline
\end{tabular}

Table 12: How the King Gets the Materials to Pacify and Sacrifice in the Celebration Source: Field Survey 2019

From the Table above, sixty-eight percent of the respondents said the king supplies those materials from his own pocket and sometimes donations from the sub-chiefs, well-wishers, and clubs and possibly from the District Assembly. However, thirty-two percent of them claimed he rather gets them from the sales of the skin's land.

\subsection{Cost of the Festival on Families}

The researcher wanted to know the financial implications of the festival on families. Thus, they were made to indicate whether it costs the families to celebrate the festival or not and their views were captured in the Table below:

\begin{tabular}{|c|c|c|}
\hline Responses from Respondents & Frequency & Percentage \\
\hline Yes & 90 & 90 \\
\hline No & 10 & 10 \\
\hline Total & 100 & 100 \\
\hline
\end{tabular}

Table 13: Response as to Whether the Festival Costs Their Families or Not Source: Field Survey 2019

From the Table above, ninety percent of the respondents said that the festival costs their families stating a reason that during the festival so much food is wasted and also some new dresses will have to be sewn including smock for members of their families. But, ten percent of them said that it does not cost their families. 


\begin{tabular}{|c|c|c|}
\hline $\begin{array}{c}\text { Responses from } \\
\text { Respondents }\end{array}$ & Frequency & Percentage \\
\hline Yes & 89 & 89 \\
\hline No & 11 & 11 \\
\hline Total & 100 & 100 \\
\hline
\end{tabular}

Table 14: Response as to Whether Is Too Costly

Source: Field Survey 2019

According to table 14 above, eighty-nine percent of the respondents accepted the fact that its celebration is too costly with a reason that items such as cow, rice, maize, guinea corn for pito, water, etc. have to be bought. And also, that during the celebration, money needs to be given to the tom-tom beaters in the cause of drumming and dancing. Also, that some unofficial holidays are normally observed and this cost so much so long as the celebration of the children is concerned since the holidays do disrupt the academic calendar. But, eleven percent of them claimed that the cost does not exist not to talk of its being much since the purchase of the materials needed for the celebration by a household is not compulsory and, it is optional depending on one's ability.

\subsection{Minimizing the Cost involved in the Celebration}

The Table below indicates how the cost associated with the celebration can be minimized.

\begin{tabular}{|c|c|c|}
\hline Responses & Frequency & Percentage \\
\hline The days should be reduced to two days & 68 & 68 \\
\hline The days should be reduced to five days & 5 & 5 \\
\hline Practice of family planning & 27 & 27 \\
\hline Total & 100 & 100 \\
\hline \multicolumn{2}{c}{ Table 15: How to Minimize the Cost of the Celebration } \\
Source: Field Survey 2019
\end{tabular}

From the Table above, sixty-eight percent of the respondents suggested that the days for the celebration of the festival should be reduced to two days since that could help minimize the waste incurred to resources during the celebration. But twenty-seven percent of them rather lay emphasis on family planning since the more children one has the more expenditure he incurs during the celebration. This is because more new cloths, especially smocks, are going to be sewn for all members of the family. However, five percent of them suggested that the days should be reduced rather to five days instead of eighteen days used in its celebration.

\subsection{Effects of Damba Festival on Farming}

The Table below indicates the responses of respondents on the effects of damba festival on the farming activities of the people of Yendi:

\begin{tabular}{|c|c|c|}
\hline Responses from Respondents & Frequency & Percentage \\
\hline It affects farming activities & 93 & 93 \\
\hline It does not affect farming activities & 7 & 7 \\
\hline Total & 100 & 100 \\
\hline
\end{tabular}

Table 16: The Festival's Effects on Farming Activities

Source: Field Survey 2019

The Table above showed that, ninety-three percent of the respondents said that the festival affects farming activities because, that during the celebration, farmers are forced to abandon their farming activities especially on those days such as on the eleventh day, the seventeenth day and on the eighteenth day since these days are the actual days of the celebration. That after the celebrations are over sometimes the farmers become tired that they cannot immediately go to their farms and this can affect their yields since the weeds may outgrow the crops. But, seven percent of them claimed that it does not affect farming activities because during the time of the celebration of the festival farmers are less busy since the festival comes off in the dry season.

\subsection{Effects of Damba Festival on Marketing Activities}

The Table below shows the responses of respondents on the effects of damba festival on marketing activities of the people of Yendi: 


\begin{tabular}{|c|c|c|}
\hline Responses from Respondents & Frequency & Percentage \\
\hline It affects marketing activities & 98 & 98 \\
\hline It does not affect marketing activities & 2 & 2 \\
\hline Total & 100 & 100 \\
\hline
\end{tabular}

Table 17: The Festival's Effects on Marketing Activities

Source: Field Survey 2019

From the Table above showed that ninety-eight percent of the respondents affirmed that the celebration of the festival affects marketing activities both positively and negatively. That positively, due to the population increase in the town as a result of the festival, more of their goods are sold. But adversely, that there could be shortage of the basic goods in the market which may force prices up. And also, that some sellers close down their stores and attend to the festive ground to observe the celebration and lowers down their sales. But, two percent of the respondents rather hold the view that the marketing activities are not affected in any way by the celebration.

5.16. Effects of Damba on Official Work

The Table below indicates the responses of respondents on the effects of damba government workers in Yendi:

\begin{tabular}{|c|c|c|}
\hline Responses from Respondents & Frequency & Percentage \\
\hline It affects office work & 76 & 76 \\
\hline It does not affect office work & 24 & 24 \\
\hline Total & 100 & 100 \\
\hline
\end{tabular}

Table 18: Response as to Whether the Festival Affects Office Work

Source: Field Survey 2019

From the Table above, the respondents who claimed that the festival affects office work are seventy-six percent and their reason is that on the climax days of the celebration such as on the eleventh day, the seventeenth day and possibly the eighteenth day, the workers who are very much interested in the festival go to observe its celebrations. Some of these officer's close work early and even go to the extent of absenting themselves from work. However, twenty-four percent of the respondents were of the view that the celebration does not affect office work claiming that the more interesting segments of the festival come after office work, by which time the officers would have closed from office.

\subsection{Effects of the Festival on Home Activities}

The Table below indicates the views of respondents on the effects of damba festival on household chores of the people of Yendi:

\begin{tabular}{|c|c|c|}
\hline Responses from Respondents & Frequency & Percentage \\
\hline It affects home activities & 87 & 87 \\
\hline It does not affect home activities & 13 & 13 \\
\hline Total & 100 & 100 \\
\hline
\end{tabular}

Table 19: Responses as to Whether the Festival Affects Home Activities

Source: Field Survey 2019

The Table above showed that eighty-seven percent of the respondents accepted the fact that the celebration affects home activities claiming that on the festive days many people including home wives and children go to observe the celebration. This makes the domestic chores carried out by the house wives and the children come to a halt until the festivities are over. But, thirteen percent of them claimed it does not affect home activities because most of the time those to carry out such chores see to their completion before they go to observe the festivities.

\subsection{Effects of Damba Festival on Marriage}

The Table below indicates the responses of respondents on the effects of damba festival on marital life of the people of Yendi:

\begin{tabular}{|c|c|c|}
\hline Responses from Respondents & Frequency & Percentage \\
\hline It affects marriages & 95 & 95 \\
\hline It does not affect marriages & 5 & 5 \\
\hline Total & 100 & 100 \\
\hline
\end{tabular}

Table 20: The Festival's Effects on Marriages

Source: Field Survey 2019

In responding to whether the celebration of the festival affects marriages, ninety-five percent of the respondents claimed that it affects marriages. They said that divorces may occur since the house wives are likely to incur the displeasure of their husbands for not coming home to prepare supper on time and, also the house wives are being accused 
of immoral act. Also, that some may obtain new partners during this time of the year, thus encouraging marriages. However, five percent of them claimed that it does not affect marriages in anyway.

\subsection{Children Observation of the Celebration}

As to whether children are allowed to observe the celebration of the festival, all the respondents affirmed to that fact claiming that children are allowed fully to observe the celebration of the festival without any restrictions.

\subsection{Safety and Security of Children during the Celebration}

The Table below indicates the views of respondents on safety and security of children during the celebration of damba festival.

\begin{tabular}{|c|c|c|}
\hline Responses from Respondents & Frequency & Percentage \\
\hline Children are not secured & 82 & 82 \\
\hline Children are secured & 18 & 18 \\
\hline Total & 100 & 100 \\
\hline
\end{tabular}

Table 21: The Care and Security of Children in the Celebration

Source: Field Survey 2019

It was observed from the above Table that eighty-two percent of the respondents said that the children are not really secured. This is because, that during the celebration process musketries are fired which is dangerous to the lives of the children and, that the crowd at the king's palace could also cause stampede, and the children are vulnerable to the damage that may be caused by the stampede. However, eighteen percent of them said that the children are well secured since their brothers and sisters cater for them during the celebration.

\subsection{Response as to How the Celebration of the Festival Affects Education in Yendi}

All the respondents said during the celebration of the festival children refuse to attend school and rather attend to the festive ground which mars their learning process. Also, that some unofficial holidays are observed which goes to affect children and that some parents spend so much of their resources on the celebration to the neglect of school fees of their children. Thus, all these contribute to the high drop-out rates in Yendi. However, they emphasized that the celebration impacts positively as well as on the children since their cultural or traditional values are inculcated into them

\subsection{The Celebration of the Damba Festival as was Narrated by Dugu Wulana Alhassan, one of the Interviewees}

\subsubsection{How the Damba Festival Is Celebrated}

\subsubsection{The Preparatory (Napag' ba Damba) Phase}

This phase starts upon the appearance of the Damba crescent. The chief of the tom tom beaters (Namo Na) after having reminded Ya-Na, the King of Dagbon of the past Kings of Dagbon (his ancestors) through songs of praises will inform him finally that the crescent has appeared and that he should celebrate Damba. After dinner in the night, the tom tom beaters will gather at the King's palace where the celebration commences. These tom tom beaters will drum for people to dance in front of the palace. Usually, this part of the festival is considered the practice stage since people will dance to get themselves prepared for the actual days of the festival.

While the drumming and dancing process is going on, the wives of the King led by the second wife (Kazia as she is called) will be gathered singing songs of praises to the past kings generally and to their husband particularly. An illustration of one of their songs of praises is found below:

'O wumda $O$ wumda

Ka a Yeba Wumda Bawna

Ti Yeb Wunda

Nam Alassani Zoo

Ti yeb Wumba, Bawna'

In English, it goes like this:

'He hears, He hears

And Your Grandfather hears, Lion

Our Grandfather hears, the heir of Alhassani

Our Grandfather hears, Lion

This phase of the festival is also called Napagba Damba (the Damba of the King's wives). It occurs during the night after every dinner and continues until after the ninth night of the appearance of the Damba crescent. Every night is characterized by drumming, dancing and singing of songs of praises.

\subsection{SomoDamba}

This is the second phase of the festival which comes on the eleventh day of the Damba month. It is celebrated to mark the birth of Prophet Mohammed (SAW), but its activities start on the tenth day where the subjects (Kpambaliba as they are called) and Muslim clerics gather at the King's palace. These subjects include Mba Dugu, Kuga Na, Zohi Na, Balo $\mathrm{Na}$, Yidan Moli, Yani Limam among others. 
Mba Dugu, who is closer to the King will contact the King for some quantity of rice. This rice will be spread on a mat in a pavilion where the subjects and the Muslim clerics led by YidanMoli are seated and some pebbles are picked from the spread rice. While the pebbles are being picked from the rice, the tom tom beaters complement it with some drumming and Yidan Moli will be reciting some verses from the Quran.

After the picking of the pebbles from the spread rice, Damba will be staged for only the close collaborators (Wulana Nima as they are called) of the King's subjects and after all of them have finished dancing the sub-chiefs or subjects will leave the King's palace for their various homes. Some of the close collaborators of the subjects are Dugu Wulana, Balogu Wulana, Zohi Wulana, Malli Wulana among others.

The eleventh day of the month of Damba is the most active day of 'Somo Damba' and on this day, the subjects together with Malams (spiritualist) will gather at the palace. A cow, supplied by the King, will be given to a subject called Ngubkahi Na (the chief of those who chew raw things) who will tie it to a peg at the fore court of the palace while Mba Dugu goes into the palace to fetch the king out.

When the king finally comes out, together with the subjects and spiritualists, he will dance round the cow with Yidan Moli (chief spiritualist) in front of them. The drumming is done by Namo Na and his followers. The dancing round the cow is done three times before it is slaughtered. But, after every round, some verses of the Quran are recited by the spiritualists, some of which are captures below:

\section{'IllalaaYaaayuha-lazinaaamanu}

Sallalaamaa-ahasanumaafii-illimulahi

Salaatudaa-imatubidawaamimulchi-lahi

Mala kuutukulla-sheiWa-ileihiturije-uuna'

Meaning:

'Oh you who believe pray for him

What nice/good is that which is in the knowledge of God?

A perpetual prayer for the perpetual dominion of God

He who has power over everything

And unto Him shall you return'

After the cow is slaughtered, the King will collect the knife used to slaughter it and the blood on it is used to touch his forehead. This is imitated by the subjects such as Mba Dugu, Kuga Na among others. The throat of the cow is cut and pierced into a spear and Yidan Moli (chief spiritualist) will dance with it to show to the King who will be sitting in the pavilion. This is replicated by his family members. Because of this, that phase is also called 'Mole Damba' since the basic activities in this phase are normally usually carried out predominantly by Moli and his family. While Moli is dancing, money from the King through Mba Dugu will be given to Na Zo (king's friend) to be given to him since he cannot be called to collect money because of his status.

The slaughtering of the cow is done during the morning segment of the celebration but the subjects of the King such as Kuga Na, Zohi Naa, Mba Malli to mention just a few do not dance. It is only their collaborators (Wulan Nima) who dance. However, Mba Dugu also dances. The slaughtered cow will then be given to a butcher by name 'Ngubikahi Na' who cuts the meat into pieces and the rice which was polished the previous day is bought out. Mba Dugu does the sharing of the rice and the meat to some particular elders, who among them are: Balo Na, Zohi Na, Kum Lana to mention just a few. The surplus rice and meat are given out to the wives of the King to cook for the guests.

The tail of the slaughtered cow is cut by 'Kum Lana' for keeps which finally will be counted to determine the number of years the King (Ya-Na) has reigned the people after his demise. The drumming and dancing continue till some time when the drummers and the dancers will break for lunch and then resume for the next stage of Somo Damba (Moli Damba). At about 3:00pm, the drumming and the dancing again resume at the palace till about 6:00pm when the participants again will break for dinner. Here, it is not only children who do the dancing but also the elderly. Gban Zaling (senior wife of the King) also takes part in this stage. She comes out with her co-wives some of whom include Kazia, Katini, Litugim, Galibanga, Tondong, Tibogu, Pariwaa, Bogupani to mention just a few. The King is the last person to dance to bring to an end the afternoon Damba.

At about 9:00pm, after dinner, they again resume for the final stage of SomoDamba (MoliDamba) at the palace. Here, as the men dance, the women too form a group at one side of the palace and also sing songs of praises. This continues till day break. While the drumming and dancing go on, the King will come out with Mba Dugu and, through Mba Dugu; he will give out some money to the dancers. Usually, he comes out on three occasions during the night celebration specifically two hours interval. All the subjects will leave the palace for their homes thus, bringing to an end Somo or Moli Damba.

\subsection{Naa Damba}

On the sixteenth day of the month, the picking of the pebbles from spread rice on a mat in the middle of the subjects and Mallams seated in a pavilion at the palace is again done as observed on the tenth day of the Somo Damba. In fact, this phase of the festival is considered a bigger one as compared to the Somo Damba, the second phase. It is celebrated to mark the naming of Prophet Mohammed (SAW). The morning, the afternoon and the night sessions are organized in the same way as they are done during Somo Damba. The difference lies not in the organization but in the number of people who attend the Damba. The King again attends both the morning and afternoon sessions and also in the night he comes out intermittently to see how the dancers are faring in their celebration. Before the start of the morning session on the seventeenth day of the month, the King sits in state to receive homage from his sub-chiefs, village headmen, senior princess and other customary dignitaries. 
The village headmen are enjoined by custom to bring to the King fowls or guinea fowls, foodstuffs and sometimes cash. These gifts are of great assistance to the King in the celebration of the festival. He gives part of the foodstuffs and birds to the senior princesses whom he refers to as his 'aunts'. He gives some of the money as enjoined by custom to elders and senior princes who attend the various sessions and spend a lot of money by giving it to the dancers for the benefits of the drummers. The money is particularly to assist the elders and senior princes during the night when customs expect them to spend the whole night dancing at the palace.

On the seventeenth day, the subjects, the elders and the Mallams get back to the King's palace around 9:00am during which time the King will come out and again dancing round a cow three times before the cow will be slaughtered. While that is done, Yidan Moli will again recite some verses from the Quran. The King will use the knife used to slaughter the cow with the blood to touch his forehead. The slaughtered cow will be prepared by 'Ngubkahi Na' by cutting the meat into pieces. This cut pieces of the meat and the polished rice will be shared by Mba Dugu to particular personalities and what is left is given to the King's wives to cook for the rest to eat.

The afternoon session for the Naa Damba usually starts early. This is to enable as many people as possible to get the opportunity to dance. During this session also, the King does not take floor early when he sees that there are many persons who want to dance. The festivities for the afternoon end when the King dances. When and where for some reason the King does not dance, an important Prince or Elder takes his place and brings the ceremony to an end.

In the night of Naa Damba, after dinner, another Damba festivity is organized at the palace. Although the attendance at this nocturnal session is not large, the session is the longest one. It starts around 9:00pm and lasts till day break. The King does not fully take part in this session as done during the morning and the afternoon sessions but intermittently comes out to see how the dancers go about the festivity. He comes out on three occasions usually two hours interval. The King brief appearances do not only encourage the dancers but it shows his concern for Dagomba tradition and the torch bearers of Dagomba custom and culture. The session is patronized by the elders and princes and persons who are great lovers of Damba dance. They have real opportunity to dance as many times as they like. The night Damba is not colorful but can be lively as the afternoon Damba. It is during this session that the expect dancers do really display their mastery of Damba dance and related royal dances. One of the likeable features of the night Damba is the melodious chanting of a large number of women. It is in this night they put into practice all the good and festive captivating songs they learned since the beginning of the Damba. In their chants, they eulogize the King and their own ancestors and they praise the good works of the men and women of the town. They also praise God for His beneficence and mercy. Dancers in the night give money not only to the tom tom beaters but also to the chanters. This festivity continues till day break. The drummers and the dancers again disperse to their various homes waiting for the evening when they will have their Belikulisi, the final phase of the Damba. Meanwhile on their way home, the elders, particularly, Zohi Naa will first go to Balo Naa's house, Yidan Kambala's house among others and say hello and good morning to them before he gets to his house. The end of the Naa Damba marks the end of the naming of Prophet Mohammed (SAW).

\subsection{Belikulisi}

This is the final phase of Damba festival and it means 'Seeing Off' of the festival. It comes off on the eighteenth day of the Damba month. On this day, the King will tell Mba Dugu, his senior elder, to go and extend his gratitude to the other sub-chiefs or elders who assisted him to see through the festival successfully. At about 3:00pm, everybody including some of the wives of the King will be gathered in front of Mba Dugu's house. They normally wear their best smocks and clothing. Mba Dugu then comes out, mounts on his horse back. They then move towards the west direction of Yendi. Firstly, they go to some of the subjects' houses who intend join them for the seeing off to be done.

It may agitate people's mind as to why the people do not gather at the King's palace this time around but, rather at Mba Dugu's house. The reason is that Mba Dugu is next to the King ceremoniously and as well as a collaborator who takes responsibility of this nature on behalf of the King although his representatives are normally included, who his wives are. Usually, the other elders who join Mba Dugu to do the seeing off are also found on horseback. This people on the horse back will then match to Zohi Naa house where the seeing off started. From there, they move to the Kumlana's house, Zongo Naa's house, Yidan Kambala's house, Yidan Baba's house, Zohi Nakohi Naa's house, Gagbun Dana's house among others. While these movements are going on, the wives of the King are also singing some of their songs of praises one of which is captured below:

'Ben $n$ daa nya dibe lala

Nti la nya kadi ka lala Ben n daa nya

Tibung Adamabia key nyakadibelala

Nti lan nya kadi pa lala Ben daa nya

Ben daa nya kadi nya la dogim

Nti lan nya kadi pala kpili Ben daa nya'

Meaning

'They saw it like that and re-saw it and it is not like that

The son of Tibung Adama you saw it like that and saw it again

And it is not like that.

You saw it and it was a family issue and saw it again and it is not a

Family issue'

In each of the house visits, Mba Dugu will extend to the sub-chiefs the gratitude of the King after he Mba Dugu is received by the sub-chief who has been visited by him with some kola nuts. All these movements are accompanied by intense drumming and dancing and some chants from women. Mba Dugu will tell these sub-chiefs he has seen Damba off till the 
following year. Everybody then returns to his or her home in order to rest and think about the next coming year. This scene marks the end of the festival.

\subsection{Contribution of the Festival to National Development}

The festival plays a significant role in Ghana's cultural heritage. Therefore, if more attention is given to develop this festival, it would create an exciting attraction in the host community; and would consequently attract a good number of visitors both domestic and international. The desire for festivals and events is not specially designed to address the needs of a particular group. More often than not, the hosting of such events is meant to develop the tourism and economic opportunities in those communities aside the social and cultural benefits associated with the celebration. Also, the festival can play a major role in the cities and local communities; as it promotes local pride and provides a sense of identity for the local people. The festival also plays a critical role in destination planning which can enhance tourism and commerce. For instance, the festival can serve as an image protector, economic generator, tourist attraction, overcoming seasonality and also to the development of local community and businesses. The festival therefore, plays a crucial role in the development of not only the socio-economic, environmental and political spheres of lives of the people of Yendi but also contributes significantly to cultural tourism development in the area.

\section{Summary of Findings, Conclusion and Recommendations}

This part looks at the summary of findings and the conclusion drawn from these findings. It also looks at some recommendations as to what is to be done to improve upon the celebration of the festival for the benefit of the people of Yendi in particularly and the nation as a whole.

\subsection{Summary of Findings}

In this study, finding is made about the celebration of the festival. It is revealed in the previous part that the festival is celebrated in four phases comprising the preparatory phase, which is also called the 'Napagba Festival' (Damba for the King's wives). This phase of the festival is full of drumming and dancing coupled with the singing of the songs of praises by the wives of Ya-Na, the King of Dagbon upon the appearance of Dmaba crescent from the first day up to the ninth day of it.

The second phase of the festival comes off after the picking of pebbles from spread rice on a mat in the King's palace on the eleventh day of the month. This second phase is also called 'Somo' or 'Moli' Damba because it is named after the chief spiritualist by name Moli, who is the major character in that phase of the celebration.

The third phase comes off after picking of pebbles from spread rice on a mat at the king's palace on the seventeenth day of the month. This phase is also known as 'Naa Damba' or 'Big Damba'. It is called Naa Damba because the King is the major character in this phase. This is because; he fully participates in the celebration in this very phase.

Finally, the fourth phase, which is also known as 'Belkulsi' (seeing off) comes off on the eighteenth day evening. The second and the third phases signify the commemoration of the birth and the naming of Prophet Mohammed (SAW) respectively. It also serves as a platform during which the King resolves disputes and unifies his subjects. In each of these phases, that is the second and the third phases of the festival, a cow is slaughtered after some rounds are made to it by the King and Moli together with some subjects on the festive ground. Whiles the rounds are made to the cow, some verses of the Quran are recited by Moli, the chief spiritualist. The celebration of the festival occurs through the principal streets of Yendi and finally staged at the king's palace where the necessary events are held.

The celebration of the festival started in the sixteenth century by a great King called Naa Zanjina, who reigned Dagbon between 1648 -1677. In the course of the celebrations, all the materials needed for the pacifications and sacrifices such as cow, etc. are provided by the king from his own pocket and sometimes through donations from sub-chiefs, well wishes, the District Assembly and from sales of skin land.

Also, finding was made about the socio-economic impact of the festival on the people of Yendi. The study found out about areas such as education, social, economic, religious and cultural impact of the festival on the people of Yendi.

Educationally, it is found out that the festival teaches the people of the area to be more respectful to their elders since on the festive grounds they observe how their parents or the subjects of the King pay homage to him, the king. Through the festival the people also learn the rich cultural elements of that traditional area. This is because in the course of the festivities, whoever is chosen to dance must first, as a laid down rule, go to squat before the King who in turn gives money through Mba Dugu to him as a sign of permission to go out and dance. Consequently, they directly maintain and practice the said cultural elements. The people also acquire some leadership skills since they observe the traditional leaders perform their duties at various stages on the festive grounds. Also, some sense of punctuality is inculcated in the people as they observe at various stages of the celebration-the early attendance of the traditional leaders to the festive grounds. They keep it up when finally, it comes to their turn. Finally, the people are offered the opportunity to learn, practice and maintain the history and some of the traditional values of their ancestors. However, on a more adverse note, the celebration of the festival makes some unofficial holidays to be observed which sometimes obstructs the academic calendar. Also, some parents during the festivities dissipate their resources which sometimes makes it impossible for them to pay their children's school fees, thus increasing the dropout rate in the area, especially at both the Junior High School and the Senior High School levels.

Socially, it was revealed that the festival promotes unity since it symbolizes the period of togetherness. It is during this period that all families and clans come together and share ideas. Also, during this period, old cases such as disputes within families are settled by all the family members. Therefore, its celebration cements social relationship. The study also revealed that the festive grounds serve as a place for courtship and people could obtain their partners from there to marry. 
However, the celebrations sometimes lead to chaos in families, thus breaking up marriages since house wives and children sometimes abandon house chores such as preparing supper among others and go to observe the celebration. The house wives may even be accused of engaging in immoral acts all in the name of the festival.

Economically, the study showed that those who could not farm owing to financial constraints, through the festival, are offered help either in kind (seeds) or in cash by the elders to help them during the faming season. The elders even offer them counseling to be hard working since success depends so much on this. Also, during the festivities, the population of the area swells due to the villagers and natives coming from the urban areas to observe the festival. Eventually, those who sell in the market have their sales increased due to the numerous guests. But it was observed that most of the farmers abandon their farm works and only go back to it after the celebration, which affects their yields since weeds may out -grow crops as a result of their absence from the farms due to the celebration. Most of the office workers also close work early and some even abandon office work especially on the climax days of the celebrations. For the market, rise in population leads to shortage of basic goods in the market, thus bringing about rise in prices of those goods. Most of the times, conditional sales, hoarding and black - marketing become the order of the day.

Religiously, it was revealed that the festival models the life of the people in Yendi to reflect the teachings of the Islamic Religion. This is because; the festival exposes the people of Yendi to the various stages of the life of the Holy Prophet Mohammed (SAW). Also, the people get to know that most of the traditional cultural elements move in line with the religion as they observe the King together with mallams and some other elders moving around the cow and reciting some verses from the Quran. This, therefore, makes the religion continuously practiced and maintained. However, the festive grounds leave many of the people confused regarding how to distinct religion from tradition since most of the activities are carried out traditionally amidst religion.

Again, it was realized from the study that the festival offers an opportunity for the people to plan how to develop the town. In this regard, each and every one gives suggestion as to how to develop the town and, some contribution either in cash or in kind is made to that effect.

Also, it was observed from the study that the celebration of the festival poses threat to the lives of children of the area during the festivity. For instance, sometimes the crowd at the palace usually causes stampede due to the firing of musketeers during the celebration, which all threatens children's life. Some of the children even get missing especially after the evening sessions of the festival which sometimes travel into the night.

Finally, it was revealed that the festival can play a major role in the cities and local communities; it develops local pride and identity for the local people. It could also have an important function in the national and host community in destination planning which could enhance and link tourism and commerce. This could include image protector, economic generator, tourist attraction, overcoming seasonality and also to the development of local community and businesses. In this sense therefore, the festival is of focal importance in the development of not only socio-economic, environmental and political spheres but also cultural tourism if more awareness is placed in this sector through promotion to improve on the image of the destination for its benefit.

\subsection{Conclusion}

In my view as the researcher, the conclusion is that the festival is related to the Dagbon traditional area. Therefore, problems identified with its celebrations including its effects on education, social, economic, religious and cultural lives of the people are not confined to the area under study but are applicable to other areas of the country where traditional festivals are so much desired, cherished and seen as cultural enrichment.

\subsection{Recommendations}

Having reviewed at length the celebration of the Damba festival by the people under study and its impact on them, the following recommendations are advanced to make the celebration of the festival more beneficial to the people under study particularly and the country at large.

First and foremost, a close study of the activities related to the festival revealed that most of the educational part of the festival comes off during the night. For example, the final stages of both the 'Somo Damba' and the 'Naa Damba' come off in the night and, since many of the people cannot keep up to the night; they do not observe much of the vital activities related to the festival. More so, if they are able to keep vigil, it affects their productivity since most of them are farmers. Therefore, I recommend that in the interest of the people of Yendi in particularly and the nation at large those stages of the celebration that occur in the night should be made to come on in the day time.

Secondly, it was observed that the elders dominate the various activities carried out in the course of the celebration especially in the drumming and dancing. This does not make the people, especially the youth, to learn very perfectly the cultural heritage of the traditional area. Therefore, I recommend that the youth should be well integrated in all the activities of the celebration in other to be more conversant with the celebration of the festival. It is only when they are allowed fully integrated into the celebrations that they can assimilate very well the celebration of the festival or the cultural heritage of the traditional area.

Furthermore; it was brought to light in the study that in the course of celebration of the festival certain rituals are performed without explanation as to what they mean. For example, the picking of pebbles from the spread rice on the mat, the dancing round the cow to be slaughtered and piercing of spear to a cut throat of the slaughtered cow which the chief spiritualist dances with to be shown to the King, among others. All these are done without clear explanation as to why specifically they are carried out. For the people to be well informed about everything regarding the cultural heritage of the Dagbon, the researcher recommends that such rituals, as mentioned above, have to explain in long with their performance. 
Also, this aspect of the celebration could be informally integrated into the school curriculum where it will be explained to the pupils of the area to enable them get the full benefits of the celebration.

Also, it was realized that the celebrations occur through the principal streets of Yendi and finally staged at the king's palace where everything is carried out. Sometimes where the king's palace is not large enough to contain everybody who wants to observe the festival, it eventually leads to stampede. This occurs especially when a great personality is arriving on the festive ground or when the king himself is about to dance or when musketeers are being fired. All these do not ensure full security of the feeble ones especially children. Therefore, I suggest that an extensive or a very wide area could be found in Yendi for the celebration of the festival since that can help provide some security of a sort. The said area could even be outside the king's palace.

Related to the above is the fact that the celebration of the festival adversely affects children in so many ways including their security, education, to mention but a few. For instance, in terms of their education, the celebration affects the academic calendar and also makes them to become truants. In terms of their security, they sometimes get hurt and even get missing even though they are under the care of their brothers or sisters. Therefore, I recommend that the celebration should be designed, if possible, to come off during weekends or during school vacation times since that will curb the situation of the unofficial holidays that are observed. Still, law could be enacted such that children below twelve years should not be allowed to take part in the celebration of the festival since that can attend to the issue of their security and care.

It was also found out from the study that the festival takes unduly long time to be celebrated since it takes about eighteen days to be celebrated. This does not only affect the productivity levels of the people of the area as farmers but also assists in depleting their meagre resources in terms of food as a result of waste that occurs. This eventually makes it impossible for them to properly cater for their children specially, paying for their school fees. Thus, it contributes to the high dropout rates among children especially at the basic education level. To raise the productivity rates of the people of the area and to reduce the wastages caused to resources during the celebration, I suggest that the days of the festival should be reduced to five days. This is because it is observed that it is only on such five days that the major activities of the festival occur. These days include the tenth, the eleventh, the sixteenth, the seventeenth and eighteenth days of the Damba month.

From the study, it was also observed that the funding of the festival for pacifications and sacrifices were done mainly by the king from his pocket, from donations and from sales of skin land. The donations usually come from the wellwishers, family heads and, sometimes from the District Assembly, which further drains the meagre resources of the Municipal Assembly limiting their ability to execute developmental projects in the district. Therefore, to allow the Municipal Assembly to be freed from such burdens, I recommend that a traditional fund should be established where the sub-chiefs and well-wishers of the traditional area are made to contribute some money into, which will be used for the purpose of the celebration.

The study also showed that marriage couples had problems with each other for accusations of immorality on the part of women as well as their inability to get home on time to carry out their home chores which sometimes affects such marriages. To free these couples of such accusations, I recommend that the festival should be staged in the early part of the day so that it will end early enough to allow the women get home on time to carry out their duties. If possible, married women could be disallowed from attending the celebration of the festival since that could help save them from the accusations and possibly divorces that might result thereof.

Finally, it was realized in the cause of the study that not much had been written or publicized about the festival and, those that had been written or publicized are very scanty and not detailed enough. Even the celebration of the festival did not get much publicity in the national media which makes it impossible for the natives of the area particularly and the entire Ghanaians to learn about its celebration. Therefore, it is recommended that much publicity regarding its celebration, should be given by the opinion leaders of the area and the mass media. This will go a long way to enable the people from the traditional area and those outside the area as well to learn more about the festival.

\section{References}

i. Abubakr V.S (1997) Profile of Damba Festival of Northern Region. Tamale

ii. Abukari M. (2017) Impact of Ghanaian Festivals on Tourism Development. International Journal of Innovative and Applied Research, Vol. 5, Issue 7, ISSN 2348-0319.

iii. Arhin K. (1996) The Political Systems of Ghana. Sedco Publishing Limited, Accra.

iv. Chantler, C. (1973) The Ghana Story, Linden Press, London

v. Fortes M. (1940): African Political System. Oxford University Press, London

vi. Gyekye K. (2003) African Cultural Values. An Introduction. Sankofa Publishing Company, Accra.

vii. Ishaque, K. (1989) Curriculum Research and Development Division, Cultural Studies for the Junior Secondary Schools. Allied Publisher Ltd, Accra.

viii. Jafari, J. (1987) Tourism models: The Socio-cultural aspects. Tourism Management, Vol. 8, No. 2.

ix. Kousoyinnis A. (1979) Modern Microeconomics, 2nd Ed, Macmillan Press ltd, Houndmills, Basingstoke, Hampshire RG21 6XS and London.

x. Mahama I. (2004), History and Traditions of Dagbon. GILLBT Printing Press, Tamale.

xi. Melanie K. S. (2003) Issues in Cultural Tourism Studies. Rutledge, London and New York.

xii. Nukunya G.K. (2003) Tradition and Change. Ghana University Press. Legon, Accra

xiii. Pritchard. E (1940), African Political System. Oxford University Press. London

xiv. Radcliffe B. A.R. and Forde D. (1950), Marriages. Oxford University Press. London 
xv. Richards, G. (2002) Tourism attraction systems: Exploring cultural behavior. Annals of Tourism Research29 (4), 1048-64.

xvi. Sheilah, F and Clarke E. (1997) 'Traditional Festival in the Political Economy: The Case of Contemporary Ghana' Journal of Social Development in Africa, Vol. 12, No2.

xvii. Wang N. (1999) 'Rethinking Authenticity in Tourism Experience' Annals of Tourism Research, Vol.26, No.2.

xviii. Wyllie, R. W (1994) 'Gods, Locals, and Strangers: The Effutu Aboakyer as Visitor Attraction,' in Current Anthropology, 78-81. 